\title{
KONSEP AGAMA-AGAMA DALAM MEMBINA KERUKUNAN ANTAR UMAT BERAGAMA
}

\author{
Kamaluddin \\ Universitas Islam Negeri Sumatera Utara (UINSU) Medan \\ kamaluddindalimunthe2@gmail.com
}

\begin{abstract}
Abstrak
Apabila penganut agama memahami secara baik dan benar agama yang dianutnya, dan diamaalkannya pula dengan baik dan benar ajaran agama tersebut, maka sudah dapat dipastikan kerukunan antar umat beragama dapat diwujudkan dalam kehidupan bermasyarakat dan bernegara. Sebaliknya bila pola keberagamaan umat masih bersifat formalisme yang kering dengan nilainilai spiritual dan moralis, bukan tidak mungkin agama menjadi salah satu faktor yang mendorong terajdinya komplik di tengah- tengah masyarakat.
\end{abstract}

Kata Kunci: Agama, Membina, Kerukunan dan Umat.

\section{Abstract}

If religious followers understand the religion they adhere to properly and correctly, and practice the teachings of that religion properly, then it is certain that harmony between religious communities can be realized in the life of society and the state. In fact, if the religious pattern of the ummah which is formalism is dry with spiritual and moral values, it is not impossible that religion will become one of the factors that encourage the existence of complications in society.

Keywords: Religion, Fostering, Harmony and People.

\section{Pendahuluan}

Manusia sebagai makhluk individu sekaligus makhluk sosial senantiasa membutuhkan aturan dan norma untuk menjamin kedamaian, ketentraman dan kenyamanan hidupnya dan hidup orang lain. Sesungguhnya aturan dan norma yang diciptakan akal manusia, tidak berada pada posisi yang selalu benar dalam menciptakan norma dan nilai-nilai yang dapat diterima oleh semua pihak dan golongan, sebab akal manusia selalu dipengaruhi oleh lingkungannya, oleh karena itu maka, menjadi tugas manusia yang sadar akan hakikat eksistensinya, atau para penganut agama untuk merealisasikan misi agama- agama itu. Mereka wajib menerjemahkan nilai-nilai ajaran agama yang bersifat blue print ke dalam sikap dan prilaku nyata yang mencerminkan secara utuh ajaran agama mereka. (Abul A'la, 
2002:6).

Pernyataan di atas memberi gambaran bahwa agama tidak hanya menawarkan sejumlah doktrin-doktrin yang harus diyakini dalam hati sanubari setiap orang secara pribadi, akan tatapi keyakinan itu harus diwujudkan dalam perbuatan nyata, sesuai dengan hakikat iman itu sendiri yaitu: diikrarkan dengan lidah, diyakini dalam hati dan diwujudkan dalam perbuatan, sebab ajaran agama memberikan petunjuk dan norma-norma untuk menciptakan hubungan sosial yang terjadi di dalam kehidupan masyarakat.

Terwujudnya interaksi sosial yang baik diantara individu-individu dalam masyarakat, sebenarnya karena didorong oleh ajaran-ajaran agama, sebab ajaran agama senantiasa mewajibkan kepada penganutnya untuk senantiasa berbuat baik dan terbaik bagi orang lain, ajaran agama mewajibkan kepada penganutnya untuk senantiasa mewujudkan perdamaian, kenyamanan dan ketentraman hidup, mencintai, menyayangi dan menghargai orang lain sebagai mana ia mencintai, mengasihi dan mengahargai dirinya sendiri. Artinya ajaran agama selalu menuntut penganutnya untuk senaniasa mampu berbuat yang terbaik pada lingkungan dimana ia berada.

Berangkat dari konsep di atas, maka dapat dikatakan bahwa agama mempunyai peran penting dalam menciptakan kedamaian dan ketentraman dalam kehidupan bermasayarakat, sebab "agama pada umumnya menerangkan fakta bahwa nilai-nilai yang ada dalam hampir semua masyarakat bukan sekedar kumpulan nilai yang bercampur aduk, tetapi membentuk tingkatan (hikarki). Dalam hikarki ini agama menetapkan nilai-nilai yang tertinggi (Elizabeth K. Nottingham, 1992:38)

\section{Peranan Agama Dalam Kehidupan Masyarakat}

Bila ditinjau dari sudut definisi, maka masyarakat dapat dikatakan "suatu sistem pada cara kerja dan prosudur, daripada otoritas dan saling bantu membantu yang meliputi kelompok-kelompok dan pembagian-pembagian sosial lain. Sistem yang kompleks yang selalu berubah atau jaringan-jaringan dari relasi sosial. (Harsojo, 1983:143).

Definisi di atas memberi gambaran pada bahwa masyarakat merupakan kelompok individu yang bersatu dalam satu wadah, mempunyai tujuan atau kepentingan bersama, tradisi, sikap dan terjalin perasaan persatuan yang sama pula.

Pada hakikatnya manusia ini tidak dapat dipisahkan dari masyarakat, sebab 
manusia senantiasa membutuhkan orang lain untuk mempertahankan kelangsungan hidupnya. Kebutuhan itu menyebabkan individu-individu manusia tersebut saling berintraksi dengan individu-individu lainnya, sehingga terciptalah sebuah masyarakat. Untuk terciptanya kelangsungan hidup masyarakat, setidaknya ada dua pokok yang dibutuhkan masyarakat tersebut, yaitu;

1. Masyarakat mempunyai kebutuhan-kebutuhan tertentu untuk kelangsungan hidup dan pemeliharaannya sampai batas minimal.

2. Agama berfungsi memenuhi sebahagian diantara kebutuhan-kebutuhan itu, meskipun mungkin terdapat beberapa kontradiski dan ketidak-cocokan dalam cara memenuhi kebutuhan-kebuthan tersebut.

Untuk terciptanya masyarakat yang baik dan stabil diperlukan nilai-nilai atau ajaran-ajaran yang dapat mendorong manusia untuk memenuhi nilai-nilai atau norma-norma serta ajaran-ajaran tersebut. Sebab bila tidak ada peraturan yang disepakati bersama oleh masyarakat, dan tidak ada pula ajaran dari keyakinan yang dimilikinya yang dapat mendorong bahkan mengikat dirinya untuk saling berintekrasi dengan orang lain, maka akan dikhawatirkan bahwa dalam kehidupan bermasyarakat tidak akan terciptakan kerukunan hidup yang harmonis, sebab masing-masing individu akan berbuat dan bertindak sesuai dengan keinginannya sendiri, akhirnya akan berlaku hukum rimba, yaitu siapa yang kuat akan memangsa kaum yang lemah.

Oleh karenanya, dalam suatu masyarakat diperlukan kewajiban-kewajiban yang harus ditaati oleh semua pihak, agar senantiasa diperoleh kata sepakat dalam mewujudkan ketentraman dan kedaimaian, sebab pada saat nilai-nilai suatu masyarakat dapat diintegrasikan dalam suatu tatanan atau sistem yang berarti, pada saat itulah anggota-anggota masyarakat dapat menuju kesatu arah dalam tingkah laku mereka.

Dorongan dan motivasi terhadap masyarakat untuk mewujudkan nilai-nilai adalah berasal dari agama, sebab agama senantiasa berperan untuk mendorong bahkan dapat memaksa individu-individu manusia untuk senantiasa menciptakan keharmonisan dalam masyarakat, dan agama dipandang mempunyai kemampuan menjelaskan apa yang akan terjadi. (Roland Robettson, 44).

Berangkat dari penjelasan-penjelasan di atas, dapat dikatakan bahwa seseorang akan merasa bersalah dan berdosa bila ia tidak melaksanakan norma atau 
peraturan-peraturan yang bersumber dari ajaran agamanya, sebab barangkali "tidak ada orang yang merasa begitu terikat kepasa sesuatu, melebihi rasa terikatnya terhadap agama. Agama paling tidak bagi rata-rata manusia adalah merupakan "kalimat Sakti" artinya segala peraturan dan anjuran yang berasal dari agama merupakan hal yang tidak dapat ditolak oleh masing-masing penganut agama, sebab penolakan dan pengingkaran terhadap ajaran agama, bagi masing-masing penganut agama adalah dosa. Disinilah barangkali peran yang dimainkan oleh agama dalam membina masyarakat. Sebab ajaran agama terlihat dapat memaksa individu manusia untuk melaksanakan norma-norma atau nilai-nilai yang terdapat di dalam masyarakat, dan juga agama menjanjikan harapan-harapan moral bagi siapa saja yang melaksanakan peraturan-peraturan tersebut, dan memberi ancaman bagi orang yang tidak mengindahkannya. (Mukti Ali, 1985:173).

Sejalan dengan hal di atas, maka menurut H. A. Mukti Ali, seperti dikutip oleh Soeroyo, bahwa agama paling tidak memiliki empat fungsi yaitu:

a. Fungsi motivatif, yaitu; agama memiliki kemampuan yang efektif untuk mendorong manusia melakukan hal-hal yang terbaik dalam seluruh aspek kehidupannya.

b. Fungsi Kereatif, yaitu; agama, disamping mendorong manusia untuk melakukan kerja produktif, juga kerja kreatif dan inovatif.

c. Fungsi sublimatif, yaitu; faktor yang dapat menyelaraskan antara kehidupan dunia dan akhirat. Agama menuntun manusia agar menjadikan Allah sebagai pangkal dan tujuan hidupnya.

d. Fungsi integratif, yaitu; memadukan segenap aktivitas manusia baik sebagai individu maupun sebagai anggota masyarakat, dalam berbagai hal antara satu dengan lainnya kurang serasi. Pemahaman agama secara benar akan menghindarkan manusia dari situasi dan kepribadian yang retak. Dan dengan keutuhan kepribadian itulah manusia akan mampu menghadapi bermacam- macam tantangan dan resiko kehidupan, yang tidak jarang memporak porandakan kehidupan manusia. (Soeroyo, 1993:102).

Pesan yang dapat ditangkap dari kutipan di atas adalah, bahwa agama seharusnya dijadikan sebagai alat dan pedoman hidup yang dapat mempersatukan dan memelihara perdamaian dan kelangsungan umat manusia, namun yang terjadi kadang-kadang justru sebaliknya, seringkali agama dan simbol-simbol keagamaan 
dijadikan sebagai alat legitimasi untuk melakukan sesuatu tindakan yang tidak jarang berujung pada terjadinya benturan atau konflik antar umat beragama, intern, bahkan antar umat beragama dengan pemerintah.

Benturan atau konflik antar, maupun intern umat beragama tidak dapat terhindarkan ketika pola keberagamaan yang berkembang pada masing-masing penganut agama, masih menonjolkan nuansa formalisme yang kering dengan nilainilai spritual dan moralis. Sedangkan nilai-nilai substansial dari ajaran agama yang bersifat "inklusif”, "moderat", "toleran” dan kasih sayang antar sesama tidak pernah tersintuh sama sekali, bahkan yang mencat kepermukaan hanyalah truth claim dari masing-masing kelompok, akhirnya agama terseret ke arena wilayah konflik sekaligus menjadikannya sebagai alat legitimasi untuk melakukan kekerasan kepada orang atau kelompok lain. Akibatnya muncullah kekerasan, penindasan, permusuhan dan kerusuhan.

Menyikapi hal ini, maka kepada semua penganut agama dituntut untuk bersikap arif dan bijaksana, serta mampu memahami ajaran agamanya masing-masing secara utuh dan benar, sebab dengan cara ini penganut agama akan menemukan pada ajaran agamanya masing-masing tentang nilai-nilai kemanusiaan universal dan egalitarian. Sebab, apabila dari masing-masing penganut agama mampu memahami ajaran agamanya secara konperhensif, hal ini akan melahirkan manusia-manusia yang dapat membangun sikap toleran dalam kemajemukan, dan pada gilirannya akan berusaha mengembangkan komunikasi dan kerjasama dalam berbagai aspek kehidupan.

Kita sekarang hidup dalam dunia yang pluralis, yaitu pluralistis dalam nilainilai, kebudayaan, tradisi-tradisi, kepercayaan-kepercayaan dan agama-agama, dimana yang menjadi persoalan pokok bagi kita semua adalah bagaimana kita semua dapat hidup bersama-sama, tidak hanya dalam perdamaian, melainkan juga bagaimana kita semua dapat saling mempercayai serta loyal satu terhadap lainnya, dan bersama-sama mempertahankan harkat (dignity) manusia sebagai manusia. (Mukti Ali, 1972:7).

\section{Konsep Ajaran Agama Hindu Tentang Kerukunan Hidup Antra Umat Beragama}

Dalam agama Hindu, ajaran "Karma Marga" merupakan suatu ajaran yang 
mampu memberikan motivasi bagi penganutnya untuk tidak mementingkan diri sendiri, sebab menurut konsep ini prestasi yang tinggi kalau digunakan untuk kepentingan diri sendiri akan membahayakan, sebab itu perlu kekebalan yang dimiliki oleh manusia itu diabadikan untuk kepentingan orang banyak. (Cudamani, 17).

Dilihat dari ajaran Karma Marga, maka pengelompokan sosial (kasta) yang terdapat dalam agama Hindu, tidak bertentangan dengan kitab Weda, sebagaimana halnya dengan "Bhineka Tungga Ika", yaitu sistem ini mengelompokkan masyarakat kepada empat kategori (tipe), ilmuan dan agamawan (Brahma), Politisi dan Meliter Kshatria), pedagang dan wira swasta (Waisya) dan kaum buruh (sudra), namun kesemuanya itu merupakan anggota badan semesta (cosmic Being), artinya bahwa Brahmana, Kshatria, Waisya dan Sudra dalam istilah falsafahnya, sekalipun berbeda kualitas dan tugas, akan tetapi memiliki semangat yang sama, dengan perkataan lain, walau berbilang tetapi satu (Adwita Sosial).

Bertitik tolak dari ajaran Adwita Sosial, maka bumi yang dihuni oleh manusia tentunya memiliki bahasa yang berbeda-beda, ritus agama yang berlainan (Dharma) sesuai dengan keadaan tempat tinggal (Atharwa Weda) oleh karenanya manusia tidak dapat tidak harus berhubungan dengan penganut agama lain.

Berdasarkan ajaran adwita Sosial, maka dalam agama Hindu dikembangkan ajaran etika atau tata susila yang berdasarkan kepada ajaran "Tattawam Asi”, yaitu mengasihi orang lain seperti diri sendiri, (Harsa Swabodhi, 1980:99) dengan dasar ajaran ini (Tattawam Asi), maka dalam agama Hindu etika berkedudukan sebagai pengetahuan tata susila, mengatur tingkah laku umat manusia agar tidak bertindak hal-hal yang menyimpang dari sabda Tuhan. Oleh karenanya etika merupakan bahagian yang tidak dapat dipisahkan dari Hinduisme, sebab ia mengatur prilaku antara manusia dengan manusia, manusia dengan Tuhan dan manusia dengan alam lingkungannya.

Menurut ajaran Hindu, untuk dapat melaksanakan ajaran Tattawam Asi dengan baik dan benar, maka ada 3 (tiga) dasar prilaku yang harus dikendalikan dan disucikan seseorang yaitu:

a. Mana Cika yaitu prilaku pikiran yang baik

b. Vacika adalah dasar prilaku ucapan atau perkataan yang baik

c. Kayika yaitu dasar prilaku perbuatan yang baik.

Dalam Rig Weda, Y. 26. 2, dijelaskan bahwa "semoga seluruh makhluk 
memandang aku dengan mata bersahabat; semoga memandang satu sama lain dengan mata bersahabat.

Dari kutipan ayat-ayat Weda di atas, maka umat yang beragama Hindu menjadikannya sebagai pedoman etika dan moral di dalam mengemban tugas dan kewajibannya masing-masing dalam kerangka kehidupan beragama, bermasyarakat, berbangsa dan bernegara dalam mewujudkan tujuan pembangunan nasional yang berdasarkan Pancasila dan UUD 1945.

Dengan berpedoman kepada ajaran "Tattawam Asi”, maka umat Hindu senantiasa dituntut untuk melaksanakan sosialisasi kehidupan beragama kea rah persaudaraan dan persahabatan antara sesama manusia, sebab hakikatnya bersumber dari yang satu (yang Maha Kuasa penakdir segala ciptaan), yang diwujudkan dalam bentuk kerukunan hidup umat beragama, baik intern agama, antar umat beragama, maupun antar umat beragama dengan pemerintah.

Pengamalan Dharma agama tidak boleh menyimpang dari petunjuk pusta suci Weda, oleh karena itu sosialisasi dan inkulturisasi nilai-nilai luhur agamanya diarahkan agar setiap umat Hindu dapat mengamalkan ajaran agamanya secara benar, bulat dan utuh di tengah-tengah kehidupan bermasyarakat, berbangsa dan bernegara. Konsep Ajaran Agama Buddha Tentang Kerukunan Hidup Antar Umat Beragama Secara umum toleransi adalah sebuah sifat atau sikap dalam bersosialisasi dengan orang-orang lain yang berbeda faham atau keyakinan dengan kita. Secara lebih spesipik, toleransi adalah sifat atau sikap menghargai pendirian atau keyakinan orang lain yang berbeda dari pendirian dan keyakinan kita sendiri. Dalam hubungan ini, toleransi beragama bermakna sifat atau sikap kita dalam menghargai agama orang lain yang berbeda dari agama kita. Dalam konteks Buddhis, toleransi beragama dapat dijelaskan lebih khusus lagi.

Dari sudut pandangan agama Buddha, toleransi beragama bukanlah hanya sifat atau sikap seseorang dalam menghargai orang lain, melainkan juga suatu kewajiban teologis. Umat Budhis dimanapun percaya bahwa toleransi beragama merupakan suatu kualitas luhur yang harus ditumbuh suburkan dalam diri umat beragama sebagai konsekwensi logis dari pelaksanaan ajaran agama Buddha. Dengan kata lain, toleransi dilihat dari kaca mata Buddhis, bukanlah suatu pilihan suka atau tidak suka, "melainkan suatu kewajiban moral dan etis kita terhadap para penganut agama lain". 
Dapat ditambahkan bahwa toleransi beragama adalah kualitas yang dapat dimiliki seseorang setelah ia mampu memperaktekkan Brahma Vihara, empat keadaan bathin yang luhur. Tampa kemampuan mengimplementasikan keempat keadaan bathin luhur ini, seseorang Buddhis belum dapat dikatakan memiliki toleransi yang hakiki sebelum seseorang memiliki keempat sikap bathin tersebut. Keempat sikap bathin tersebut adalah:

a. Metta atau Metri yaitu cinta kasih semesta yang tidak mengenal batas cakrawala, cinta kasih bagi semua.

b. Karuna yakni kasih sayang yang tidak terbatas, kasih saying yang tidak mengenal batas cakrawala dan wawasan, kasih saying bagi semuanya, tanpa perbedaan dan pilih kasih.

c. Mudita adalah perasaan sempati terhadap kebahagiaan dan kegembiraan orang lain atau simpati terhadap keberhasilan yang dimiliki orang lain dalam kehidupan ini.

d. Upekkha yaitu bathin yang seimbang, selaras dan serasi bebas dari kerusakan dan kegelisahan. (Oka Diputra, 1986: 19-20).

Bertitik tolak dari keempat sikap bathin seperti tersebut di atas, semangat toleransi sebenarnya sudah dilaksanakan oleh seorang raja Buddhis yang besar yaitu Maharaja Asoka pada abad ke 3 SM di Negeri India, dimana beliau sudah terlebih dahulu mendekritkan toleransi antar agama yang pertama di dunia, dekrit tersebut dipahatkanntya di atas sebuah batu cadas, di sebuah lereng gunung, berbunyi sebagai berikut:

"Bila kita menghormati agama kita sendiri, janganlah kita lalu mencemoohkan dan menghina agama lain, seharusnya kita menghargai pula agama- agama lainnya, dengan demikian agama kita akan menjadi berkembang, disamping kita juga memberikan bantuan bagi agama-agama lainnya”. (Harsa Swabodi, $31)$.

Dari beberapa ayat yang telah dikutipkan di atas, maka dalam agama Buddha terlihat sangat menekankan bagi penganutnya untuk saling hormat menghormati antar sesame manusia, walaupun bagi orang yang tidak sekeyakinan dengan kita, sebab menurut Buddha, tidak sepantasnya seseorang yang memiliki keyakinan (agama) yang dia anggap paling benar, lantar tidak memberi penghargaan bagi agama (keyakinan) orang lain. 
Oleh karena itu menurut umat Buddha, toleransi merupakan cermin suatu kedewasaan mental dalam beragama. Sebab beragama atau mempunyai keyakinan relegius, tidak semata-mata untuk menciptakan atau membentuk seseorang untuk mengasingkan diri dari agama-agama lain. Tetapi ajaran agama menurut Buddha memberikan dorongan untuk menjalin hubungan-hubungan dengan semua orang, bahkan semua makhluk hidup dalam rangka menjalankan prinsif-prinsif ajaran agamanya yang luhur, sehingga ajaran agama tersebut dapat menumbuh suburkan rasa kesetiakawanan terhadap semua umat manusia.

\section{Konsep Kristen Tentang Kerukunan}

Berbicara mengenai konsep agama Kristen tentang kerukunan antar umat beragama setidaknya dapat dilihat dan diperhatika ayat-ayat Injil dengan secara seksama, disana juga akan kita temukan beberapa ayat yang pada hakikatnya agar sesama umat manusia saling harga menghargai, kasih mengasihi antara sesamanya, yang bila dikaitkan dengan tujuan dari kerukunan umat beragama, maka dapat dikatakan ayat-ayat Injil tersebut membantu untuk mendukung terwujudnya kerukunan hidup antar umat beragama. Ayat-ayat dimaksud antara lain terdapat pada Injil Matius, 22:36-39, yang berbunyi:

- Guru, hukum manakah yang terutama dalam hukum Taurat, jawab Yesus kepadana; "Kasihilah Tuhan, Allahmu, dengan segenap hatimu dan dengan segenap jiwamu, dan dengan segenap akal budimu.

- Itulah hukum yang terutama dan pertama.

- Dan hukum yang kedua, yang sama dengan itu, ialah: kasihilah sesamamu, sesama manusia seperti dirimu sendiri. (Lembaga Al-Kitab Indonesia, 1982: 33).

Hal yang senada dengan pernyataan itu, juga dijelaskan dalam Injil Lukas, 6:27 yang berbunyi;

- Tetapi kepadamu, yang mendengar Aku berkata, kasihilah musuhmu, berbuat baiklah kepada orang yang membecii kamu.

- Tetapi keda kamu, mintalah berkat bagi orang yang mengutuk kamu, berdoalah bagi orang yang membencii kamu.

- Barang siapa yang menampar pipimu yang satu, berikanlah juga kepadanya pipimu yang lain, dan barang siapa yang mengambil jubahmu, biarkan juga 
ia mengambil bajumu.

Merujuk pada kutipan ayat-ayat Injil di atas, maka dapat dikatakan bahwa Injil sebagai sumber hukum dalam menentukan pola dan sikap umat Kistiani dalam bertindak, sebenarnya sangat mendukung terwujudnya sikap toleransi antar umat beragama, sebab ayat-ayat Injil di atas menuntut umatnya untuk melihat umat lain, sama seperti diri mereka, melihat diri orang lain sama seperti dirinya, dan mengasihi orang lain sama seperti mengasihi dirinya sendiri, bahkan ayat itu menandaskan kendatipun kepada seorang musuh.

Karenanya, kata Victor Tanja, "Tugas utama orang Kristen adalah bersaksi tentang Tuhan yang telah mati dan bangkit bagi dunia, sehingga umat Kristiani harus bersikap toleran terhadap orang lain. Dengan demikian, umat Kristiani tidak boleh memaksakan kehendaknya kepada orang lain, karena sama seperti Yesus di Golgota, merekapun harus bersaksi dalam kerendahan”.

Dengan demikian dapat dikatakan, seandainya penganut umat beragama mau berpegang teguh kepada ajaran kitab sucinya masing-masing, maka dapat dipastikan bahwa "Kerukunan Hidup Antar Umat Beragama" dapat diwujudkan dalam masyarakat yang pluralis. Sebab kitab suci dari ke lima agama-agama besar di Indonesia (Hindu, Buddha, Kristen Katholik/Protestan dan Islam) yang menjadi topik tulisan ini, memberikan konsep yang jelas tentang kerukunan antar umat beragama.

Sejalan dengan itu, amat menarik bila hal ini dikaitkan dengan pernyataan Pdt. Ioanes Rakhmat, STh, yang mengatakan "Orang tidak lagi bergantung pada sikap lama yang berpaham bahwa di luar Gereja tidak ada keselamatan. Gereja Katolik mengakui sifat gerejawi dari gereja-gereja lain, adanya unsur-unsur religius yang otentik di dalam agama-agama non Kristen, bahkan adanya nilai-nilai positif di dalam pelbagai idiologi. Kehendak Allah yang menyelamatkan, bagaimanapun juga bekerja di luar kekristenan dan keyahudian, dan di sana kita juga menemukan unsurunsur penataan ilahi”. (Ioanes Rakhmat, 1997:70).

Pernyataan di atas memberikan gambaran bahwa kebaikan bukanlah milik kelompok tertentu, namun disaat yang bersamaan, orang lain, juga mimiliki kebaikan yang sama. Karenanya, dalam menciptakan kerukunan umat beragama di tengah- tengah masyarakat yang serba pluralis ajakan pada Konsili Vatikan II dari pandangan Gereja Katolik pantas menjadi renungan para pemerhati pluralis dan 
para peserta dialog antar agama saat ini, yaitu:

"Maka konsili Suci mengajak semua pihak untuk melupakan yang sudahsudah, dan mengusahakan dengan jujur saling pengertian dan melindungi lagi memajukan bersama-sama keadilan sosial, nilai-nilai moral serta perdamaian dan kebebasan untuk semua orang". (Paulinus Mardame, 1994:11).

Dari konsep-konsep kerukunan yang ditawarkan di atas, maka nampaknya agama-agama menuntut kepada umatnya masing-masing untuk senantiasa menjadikan ajaran agama sebagai pengemban nilai-nilai moral dan spritual dan menjadi pejuang kemanusiaan yang tangguh, dan memiliki concern terhadap amanat penderitaan rakyat, dimana merasa gelisah dan resah tatkala hak dan martabat manusia tidak lagi mendapat tempat yang selayaknya dalam kehidupan ini.

Sebab, bila pola keberagamaan yang kita kembangkan saat ini masih berkutat dan menampakkan karakter yang sarat dengan nuansa formalisme yang kering dari nilai-nilai spritual dan moralis, akibatnya, nilai-nilai substansial agama yang bernuansa inkuklusif, moderat, dan toleran (seperti dikemukakan di atas) tidak pernah ditangkap dan diimplementasi-kan secara utuh.

\section{Konsep Islam Tentang Kerukunan}

Islam merupakan agama samawi yang terakhir diturunkan oleh Tuhan, sebagai agama terakhir, disamping ia merupakan penengah (وف اسطة), juga merupakan syaksi bagi umat terdahulu. Islam membawa ajaran yang syarat dengan konsep kedamaian, yang sesuai dengan tuntutan fitrah manusia, karenanya Islam memerintahkan umatnya "agar umatnya berpegang teguh kepada ajaran kontiniutas itu, dengan beriman kepada semua para Nabi dan Rasul Tuhan, tanpa kecuali dan tanpa membeda-bedakan antara mereka baik yang disebut dalam kitab suci maupun yang tidak disebutkan", (Nurcholish Madjid, 1993:20) hal inilah yang digambarkan oleh Allah dalam surat Al-Baqarah ayat 136:

Artinya : "Katakanlah (hai orang-orang mu'min): "Kami beriman kepada Allah dan apa yang diturunkan kepada kami, dan apa yang diturunkan kepada Ibrabim, Ismail, Ishaq, Ya'kub dan anak cucunya, dan apa yang diberikan kepada Musa dan Isa serta apa yang diberikan kepada Nabi-nabi dari Tubannya. Kami tidak membeda-bedakan seseorangpun diantara mereka dan kami hanya tunduk patub kepada- Nya". (Departemen Agama RI, Al-Qur'an dan Terjemahnya, 1971:35).

Merujuk pada ayat di atas, setidaknya ada dua hal yang perlu diketahui, yaitu; 
Pertama: ayat itu memberikan gambaran bahwa Islam sebagai agama terakhir dari proses pertumbuhan dan perkembangan agama-agama dalam garis kontiniutas dengan tegas memberikan kesaksian atau mengakui akan keberadaan agama-agama lain, pengakuan akan hak dan keberadaan agama-agama lain merupakn sikap toleran yang amat jelas yang ditunjukkan oleh Islam. Kedua; ayat itu memberikan isyarat bahwa pluralitas sosial, budaya dan agama, sebagai sesuatu yang tidak dapat dihindarkan dalam kehidupan ini, ia merupakan sunnatullah yang tidak dapat dipungkiri. Karenanya Islam tidak pernah dan tidak akan mentolerir terjadinya pemaksaan-pemaksaan untuk menganut salah satu agama. Hal ini dijelaskan Allah dalam al-Qur'an Surat al-Baqarah ayat 256:

Tidak ada paksaan untuk (memasuki) agama (Islam), sesungguhnya telah jelas jalan yang benar daripada jalan yang sesat. Karena itu barang siapa yang ingkar kepada thaghut dan beriman kepada Allah, maka sesunguhnya ia telah berpegang kepada buhul tali yang amat kuat yang tidak akan putus. Dan Allah Maha mendengar lagi Maha mengetahui.

Pesan yang dapat ditangkap dalam ayat di atas adalah: bahwa Islam memberikan kebebasan seluas-luasnya kepada manusia untuk menentukan arah hidup yang akan dia jalani. Seseorang tidak dibenarkan untuk memaksakan kehendaknya kepada orang lain yang sesuai dengan keinginannya. Sikap kebebasan dan keterbukaan (inklusif)yang ditunjukkan Islam, menjadikan agama ini menjadi agama yang amat menghargai keyakinan orang lain, karenanya Islam tidak membenarkan bahkan melarang para penganutnya untuk mencaci sembahan-sembahan agama lain. Disinilah sikap toleransi yang mendasar yang ditunjukkan oleh Ilham. Hal ini digambarkan Allah dalam Suat al-'An am ayat 108:

Artinya : "Dan janganlah kamu memaki sembahan-sembahan yang mereka sembah selain Allah, karena mereka nanti akan memaki Allah dengan melampani batas tanpa pengetahuan. Demikianlah Kami jadikan setiap umat menganggab baik pekerjaan mereka. Kemudian kepada Tuban merekalah kembali mereka, lalu Dia memberitakan kepada mereka apa yang dabulu mereka kerjakan".

Dan masih banyak ayat-ayat dalam al-Qur'an, yang pada prinsipnya menjelaskan sikap keterbukaan dan toleransi Islam terhadap keberadaan agamaagama lain. Keterbukaan dan toleransi yang diperlihatkan ajaran Islam secara hakiki akan memberikan dampak positif terhadap prilaku umatnya dalam hubungannya 
dengan orang lain. Karenanya Islam tidak pernah melarang umatnya untuk berbuat baik kepada siapapun selama orang lain itu tetap saling harga menghargai. Seperti dijelaskan dalam Surah al-Mumtahanah ayat 8:

Artinya : "Allab tidak melarang kamu untuke berbuat baik dan berlaku adil terhadap orang-orang yang tidak memerangi kamu karena agama dan tidak (pula) mengusir kamu dari negerimu. Sesunggubnya Allab menyukai orang-orangyang berlaku adil”.

Sejalan dengan penjelasan-penjelasan di atas, maka Islam memiliki kesadaran bahwa disamping manusia mempunyai derajat yang sama, juga Islam mempunyai kesadaran persaudaraan, bukan hanya terhadap orang yang seaqidah dengannya, juga dengan umat manusia secara keseluruhan, seperti yang pernah diungkapkan oleh Prof DR. H. M. Ridwan Lubis dalam sebuah pertemuan agamaagama di Asrama Haji Pangkalan Masyhur Medan, bahwa dalam ajaran Islam rasa kesadaran persamaan derajat serta persaudaraan yang tinggi bukan hanya kepada seagama (ukhwah Islamiyah) dan saudara sesama umat (ukhwah basyariyah) dan lebih luas dari itu saudara sebangsa (ukhwah Wathaniyah). Adanya kesadaran terhadap rasa persaudaraan sesama umat manusia didasarkan kepada keyakinan bahwa manusia adalah sebagai karya puncak Allah SWT. (Ridwan Lubis, 6).

Oleh karena manusia sebagai karya puncak yang dilukiskan dalam surat al-Tin sebagai “ahsani taqwin”, maka dengan sendirinya manusia harus selalau didorong untuk berikrar pada dirinya untuk berbuat yang baik (al-shalah) dan yang terbaik (alAshlah) dalam kehidupannya. Dan karena itu, seorang muslim harus selalu menghindarkan dirinya dari perbuatan yang mengakibatkan desintegrasi sosial atau jaga disharmoni, sebab missi syari'at Islam adalah untuk mewujudkan kesinambungan (al-tawasun) dalam kehidupan umat manusia.

\section{Penutup}

Agama memiliki konsep kerukunan dalam membina kerukunan umat beragama, sebab ajaran agama senantiasa mewajibkan kepada penganutnya untuk senantiasa berbuat baik dan terbaik bagi orang lain, ajaran agama mewajibkan kepada penganutnya untuk senantiasa mewujudkan perdamaian, kenyamanan dan ketentraman hidup. Artinya ajaran agama selalu menuntut penganutnya untuk senaniasa mampu berbuat yang terbaik pada lingkungan dimana ia berada. Agama mempunyai peran penting dalam menciptakan kedamaian dan ketentraman dalam 
kehidupan bermasayarakat, sebab agama pada umumnya menerangkan fakta bahwa nilai-nilai yang ada dalam hampir semua masyarakat bukan sekedar kumpulan nilai yang bercampur aduk, tetapi membentuk tingkatan (hikarki). Dalam hikarki ini agama menetapkan nilai-nilai yang tertinggi.

\section{Daftar Pustaka}

A’la, Abul. (2002). Melampani Dialog Agama, Jakarta: Buku Kompas.

Ali, A. Mukti. (1972). Dialog Antar Umat Beragama Jawa Timur. Yokyakarta

-----(1985). Beberapa Persoalan Agama Dewasa Ini. Jakarta: Rajawali Pers.

Cudamani, Pengantar Agama Hindu Untuk Perguruan Tinggi. Jakarta: Penerbit Yayasan Dharma Sarathi. Nottingham, Elizabeth K. (1992). Agama dan Masyarakat, Suatu Pengantar Sosiologi Agama. Jakarta: Rajawali Press.

Harsojo. (1983). Pengantar Antropologi. Jakarta: Binacipta.

Robettson, Roland. ed. Agama Dalam Analisis dan Interpretasi Sosiologis. Jakarta: Rajawali.

Soeroyo. (1993). Agama dan Masyarakat, et. All, Yogyakarta: IAIN Sunan Kalijaga Press.

Sadya, Wayan. (1990). Panggilan Weda. Dharma Sarathi.

Swabodhi, Harsa. (1980). Upamana Pramana Buddha Dharma dan Hindu Dharma, Yayasan Perguruan Budaya.

Harliman. Menuju Peningkatan Kerukunan Hidup Beragama. Disampaikan Pada Musyawarah Cendikiawan Antae Agama Propinsi Sumatera Utara.

Diputra, Oka. (1986). Dharma Nidya. Jakarta: BP Dharma Nusantara Bahagia.

U.P.D.D. Harsa Swabodhi. Buddha Dharma Pelbagai Yana. Yayasan Pendidikan Buddha Dharma.

Lembaga Al-Kitab Indonesia. (1982). Al-Kitab Perjanjian Lama dan Perjajian Baru. Jakarta: Lembaga Al-Kitab Indonesia.

Rakhmat, Ioanes. (1997). Fundamentalisme, Agama-agama dan Teknologi. Jakarta: PT BPK Gunung Mulia.

Mardame Simbolon, (1994). Paulinus. Kerukunan Beragama, Dialog Antar Umat 
Beragama. Medan.

Madjid, Nurcholish. (1971). Islam Doktrin dan Peradaban Sebuah Telaah Kritis Tentang Keimanan, Kemanusiaan dan Kemerdekaan. Jakarta: Yayasan Wakaf Para Madina.

Departemen Agama RI. (1971). Al-Qur'an dan Terjemabnya. Jakarta: Yayasan Penyelenggara Penterjemeh/Penafsir Al-Qur'an.

Ridwan Lubis. Corak Pemikiran Keagamaan yang Mendukung Terwujudnya Kerukunan Hidup Sosial Umat Beragama. 